\title{
Pemberdayaan Masyarakat Desa dengan Usaha Kuliner Tradisional pada Kelompok Boga Ganesha Kabupaten Buleleng
}

\author{
MADE SUDANA, I GEDE SETIAWAN ADI PUTRA, \\ NYOMAN PARINING
}

\author{
Program Studi Agribisnis Fakultas Pertanian Universitas Udayana \\ Jalan PB Sudirman Denpasar 80232 \\ Email : madesudana661@gmail.com \\ igedesetiawanadiputra@gmail.com
}

\section{Abstract \\ The Village Community Empowerment With Traditional Culinary Business in the Group of Boga Ganesha Buleleng}

The development of fast food must be balanced with the consumption of traditional foods because fast food is allegedly to be a risk factor for the emergence of various diseases. This study aimed to analyze the behavior of IbIKK group of Boga Ganesha. The choice of location of the research was determined purposively with the consideration that the Boga Ganesha is one of the groups to empower the people with the traditional culinary efforts. The method used in collecting the data in this study was interviews with questionnaire instruments. Based on the research results, the potential of the IbIKK of Boga Ganesha is a kosher, hygienic and healthy traditional food processing. Behavior that was demonstrated by the members can be classified into an excellent category $(4,6)$. The achievement of the implementation of the empowerment program that is included in the category of successful $(4,2)$. Empowerment of program aimed to improve the quality of human resources. In this regard, members of the group should implement their skills so that they can open up business opportunities in order to improve the economy of the family. To support this, the facilitator should use the appropriate method so that all participants can obtain information equally.

Keywords: empowerment, rural communities, traditional culinary

\section{Pendahuluan}

\subsection{Latar Belakang}

Salah satu daerah di Bali yang memiliki tingkat kemiskinan tinggi adalah Kabupaten Buleleng. Jumlah penduduk miskin Buleleng tahun 2013 mencapai 40,3 ribu orang $(22,05 \%)$ (BPS, 2014). Salah satu penyebab terjadinya kemiskinan di Buleleng adalah kurangnya lapangan pekerjaan yang tersedia di Buleleng. Tingginya tingkat kemiskinan di Buleleng diharapkan dapat di atasi dengan program pemberdayaan masyarakat miskin (pro poor) terutama di daerah perdesaan. 
Pemberdayaan masyarakat di pedesaan dapat memanfaatkan keragaman potensi sumber daya alam (SDA) yang dimiliki Buleleng. Kenyataannya masyarakat, khususnya para remaja kini lebih suka mengonsumsi makanan serba instan, seperti fast food (Worthington,2000). Selama ini generasi muda melupakan makanan tradisional akibat tingginya pertumbuhan restoran asing (Resmining, 2014). Salah satu kelompok yang intens mengembangkan potensi SDA di Buleleng bernama IPTEK bagi Inovasi Kegiatan Kampus (IbIKK) Boga Ganesha. Program IbIKK Boga Ganesha merupakan unit usaha berbasis penelitian yang bertujuan memberi nilai tambah terhadap makanan tradisional Bali dan produk-produk makanan inovatif dan kreatif. Usaha tersebut diharapkan dapat menambah nilai ekonomis produk berbahan baku singkong sehingga meningkatkan perekonomian masyarakat sekitar.

Keberhasilan program pemberdayaan tentu tidak terlepas dari berbagai usaha yang dilakukan oleh kelompok IbIKK Boga Ganesha serta peran aktif masyarakat dalam melaksanakan program tersebut. Sebaik apapun program pemberdayaan yang dirancang, tidak akan memberi manfaat nyata bagi kehidupan masyarakat bila tidak mendapat dukungan melalui partisipasi aktif.

\subsection{Tujuan Penelitian}

Sejalan dengan perumusan masalah di atas, maka penelitian ini bertujuan untuk mendeskripsikan potensi yang dimiliki masyarakat desa yang tergabung dalam kelompok IbIKK Boga Ganesha, menganalisis prilaku (PKS) anggota kelompok IbIKK Boga Ganesha setelah mengikuti program pemberdayaan dan mengetahui tingkat keberhasilan pemberdayaan kelompok IbIKK Boga Ganeshadengan usaha kuliner tradisional.

\section{Metode Penelitian}

\subsection{Lokasi dan Waktu Penelitian}

Penelitian ini dilakukan pada kelompok IbIKK Boga Ganesa Buleleng yang beralamat di Jalan Udayana No. 11c. Waktu penelitian dilakukan pada 9 Desember 2015 s.d 9 Januari 2016.

\subsection{Penentuan Populasi dan Responden}

Populasi dalam penelitian ini adalah seluruh anggota kelompok IbIKK Boga Ganesha yang berjumlah 12 orang. Penentuan sampel dalam penelitian ini menggunakan teknik sensus, yakni menjadikan seluruh bagian populasi sebagai sampel (Wirawan, 2001).

\subsection{Teknik Pengumpulan Data, Variabel Penelitian dan Metode Analisis}

Metode yang digunakan dalam pengumpulan data adalah wawancara dengan menggunakan instrumen penelitian berupa kuesioner. Variabel dalam penelitian ini meliputi potensi masyarakat desa, perilaku kelompok dan pemberdayaan masyarakat. Data yang diperoleh dari hasil penelitian berupa data kualitatif maupun data 
kuantitatif akan disajikan dalam bentuk narasi, tabel, grafik, gambar, dan foto-foto aktual yang disusun secara sistematis dan efisien. Teknik analisis deskriptif kualitatif ini menggunakan konversi data melalui Skala Likert (Noor, 2011).

\section{Hasil dan Pembahasan}

\subsection{Karakteristik Responden}

Karakteristik meliputi usia, jenis kelamin, tingkat pendidikan dan pekerjaan dari responden. Data tersebut menggambarkan secara umum karakter dari responden daerah penelitian. Berikut akan dideskripsikan secara rinci pengelompokkan responden berdasarkan karakteristiknya.

\subsubsection{Responden berdasarkan kelompok usia}

Hasil penelitian menunjukan rata-rata resonden berusia 28 tahun. Hasil tersebut menggambarkan bahwa responden berada pada usia kerja produktif (15 s.d 64 tahun). Usia responden menjadi salah satu faktor yang mempengaruhi kemampuan kerja dan produktivitas kerja. Berkaitan dengan hal tersebut, resonden termasuk penduduk usia produktif. Chamdi (2003) menegaskan bahwa usia produktif $20-45$ tahun masih memiliki semangat yang tinggi dan mudah mengadopsi hal-hal baru. Kondisi tersebut sangat mendukung program pemberdayaan yang berusaha mendifusikan inovasi kepada responden agar cepat terjadi adopsi inovasi.

\subsubsection{Responden berdasarkan tingkat pendidikan}

Hasil penelitian menunjukan rata-rata resonden menempuh pendidikan hingga strata S-1 (15,16 th). Hasil tersebut menggambarkan bahwa responden telah menempuh pendidikan wajib 12 tahun. Semakin tinggi tingkat pendidikan responden maka akan berpengaruh terhadap produktivitas kerjanya. Hal tersebut sesuai dengan pernyataan Soekartawi (1986) bahwa pendidikan seseorang akan mempengaruhi kinerjanya dalam menjalankan usaha secara efektif dan efisien.

\subsubsection{Responden berdasarkan pekerjaan}

Hasil penelitian menunjukkan sebagian besar responden berprofesi sebagai guru $(66,67 \%)$. Pengalaman sebagai guru tentunya akan memudahkan responden dalam menyampaikan inovasi kepada masyarakat melalui berbagai metode pengajaran yang dianggap efektif dan efisien.

\subsection{Potensi}

Berbagai kebutuhan proses produksi disesuaikan dengan potensi yang dimiliki oleh masyarakat desa sekitar. Hal tersebut sangat penting agar berbagai kebutuhan dapat segera terpenuhi dan memberi tambahan nilai ekonomis bahan baku lokal. Berikut potensi yang dapat mendukung pengembangan kelompok IbIKK Boga Ganesha. 


\section{a. Sumber daya alam}

Masyarakat desa sekitar memiliki berbagai potensi sumberd daya alam (SDA), meliputi tanaman umbi-umbian, tanaman sayuran, tanaman rempah dan bahan baku hewani lokal. Beberapa hasil pertanian, perikanan dan peternakan sebagai bahan makanan lokal yang akan dijadikan bahan baku adalah beras (putih), be siap (ayam), be pasih (ikan laut), kakul (keong kecil di sawah), nyawan (tawon), blauk (capung), impun (ikan kecil-kecil), palem (udang kecil-kecil), oong (jamur bulan), dan daun jarak pagar.

b. Sumber daya manusia

Potensi lain yang dimiliki adalah kualitas SDM. Beberapa kelompok tani yang ada di sekitar IbIKK Boga Ganesha memiliki keterampilan pembuatan tepung dan produk kuliner lainnya. Kemampuan membuat tepung tentunya sangat menguntungkan karena tepung menjadi bahan baku pembuatan berbagai jenis panganan. Melalui pemberdayaan IbIKK Boga Ganesha keterampilan dari masyarakat dapat dikembangkan untuk pembuatan berbagai kuliner yang memiliki nilai ekonomis tinggi.

\section{c. Modal sosial}

Penduduk secara aktif berpartisipasi dalam program IbIKK Boga Ganesha karena mereka memiliki kepercayaan terhadap keberhasilan yang akan diraih oleh kelompok tersebut. Kepercayaan terhadap prospek usaha tersebut ditunjukkan pula oleh rasa tanggung jawab penduduk. Mereka turut serta dalam berbagai pelatihan oleh IbIKK Boga Ganesha. Putnam (2001) mengemukakan bahwa kepercayaan sosial dapat timbul dari norma timbale balik dari jaringan sosial. Keterikatan dan kepatuhan anggota-anggota masyarakat pada norma sosial memberikan hubungan timbale balik dalam satu kesepekatan aturan yang dipedomani dan dilakukan. Hal ini akan mempermudah anggota dalam mengenal dan membentuk kelompok jaringan sosial. Hal yang sama dikemukakan oleh Coleman (1988) bahwa kepercayaan merupakan salah satu kunci komponen modal sosial. Modal sosial terbentuk karena adanya kemampuan yang timbul dari prevalensi kepercayaan di dalam masyarakat atau di bagian-bagian tertentu dari itu. Adanya kepercayaan dan norma timbale balik, keadilan, kerjasama, dan manfaat yang diperoleh pada hubungan sosial, sangat penting untuk memfasilitasi dan memperkuat kelembagaan effisiensi kinerja. Berbagai tindakan kolektif yang didasari atas saling mempercayai akan meningkatkan partisipasi masyarakat dalam membangun kemajuan bersama.

\subsection{Perilaku}

Hasil penelitian menunjukkan bahwa perilaku anggota IbIKK Boga Ganesha termasuk dalam kategori sangat baik dengan skor 4,6. Data ini menunjukkan bahwa anggota IbIKK Boga Ganesha sangat mendukung pelaksanaan program yang direncanakan. Tabel 1 menunjukkan perilaku anggota IbIKK Boga Ganesha termasuk kategori sangat baik dengan skor 4,6. Kondisi tersebut menggambarkan terbukanya anggota dalam menerima program pemberdayaan. Mereka sangat 
antusias dalam mengikuti program tersebut. Hal tersebut ditunjukkan dengan partisipasi aktif selama program berlangsung. Mereka secara sukarela mengikuti proses pelatihan sehingga inovasi dapat diterima dan dirasakan manfaatnya. Berikut dipaparkan secara rinci berdasarkan aspek pendukungnya.

Tabel 1.

Perilaku Anggota IbIKK Boga Ganesha, Tahun 2016

\begin{tabular}{cccc}
\hline No & Aspek & Pencapaian skor & Kategori \\
\hline 1 & Pengetahuan & 4,5 & Sangat baik \\
2 & Sikap & 4,8 & Sangat baik \\
\hline & Perilaku & 4,6 & Sangat baik \\
\hline
\end{tabular}

Perilaku yang ditunjukkan oleh peserta tidak hanya berupa partisipasi aktif namun mereka juga membuka diri terhadap inovasi yang berusaha disalurkan dalam program pemberdayaan. Secara umum para anggota memperoleh tambahan pengetahuan sehingga ada perubahan paradigma yang terjadi dalam diri setiap anggota. Berikut akan dipaparkan secara rinci berdasarkan aspek pendukungnya.

\subsubsection{Pengetahuan}

Perilaku anggota IbIKK Boga Ganesha yang ditinjau dari aspek pengetahuan termasuk dalam kategori sangat baik, yakni memperoleh skor 4,5. Data tersebut menunjukkan bahwa para anggota mengalami peningkatan pengetahuan. Banyak informasi yang diserap dalam pelaksanaan pemberdayaan. Salah satu hal penting yang mereka pahami adalah jenis makanan. Sebelum mengikuti pelatihan, mereka hanya sekedar mengetahui makanan tanpa memahami makna yang terkandung didalamnya. Selain itu, dengan mengikuti program pemberdayaan mereka dapat menentukan bahan baku yang digunakan dalam proses pembuatan makanan sehingga dapat menghasilkan makanan yang sehat dan higienis. Secara rinci aspek pengetahuan dapat dicermati pada Tabel 2 .

Tabel 2.

Pengetahuan Anggota IbIKK Boga Ganesha, Tahun 2016

\begin{tabular}{|c|c|c|c|}
\hline No & Aspek & Pencapaian skor & Kategori \\
\hline 1 & $\begin{array}{l}\text { Makanan tradisional yang ditawarkan } \\
\text { IbIKK Boga Ganesha sangat beragam. }\end{array}$ & 4,25 & Sangat baik \\
\hline 2 & $\begin{array}{l}\text { Pengolahan yang dilakukan IbIKK Boga } \\
\text { Ganesha dilakukan dengan cara yang sehat. }\end{array}$ & 4,75 & Sangat baik \\
\hline 3 & $\begin{array}{l}\text { Sebelum disajikan ke konsumen, IbIKK } \\
\text { Boga Ganesha selalu memperhatikan } \\
\text { kemasannya. }\end{array}$ & 4,5 & Sangat baik \\
\hline 4 & $\begin{array}{l}\text { Sebelum meninggalkan ruang produksi, } \\
\text { peralatan dan tempat kerja dibersihkan } \\
\text { terlebih dahulu. }\end{array}$ & 4,58 & Sangat baik \\
\hline & Pengetahuan & 4,5 & Sangat baik \\
\hline
\end{tabular}


Tabel 2 menunjukkan bahwa pengetahuan dari anggota IbIKK Boga Ganesha termasuk kategori sangat baik. Berkaitan dengan data tersebut, mereka cepat memahami berbagai informasi dan inovasi yang disalurkan dalam program pemberdayaan. Kendati demikian, tidak semua anggota secara cepat mampu memahami berbagai informasi yang disampaikan. Perlu berbagai metode guna mempercepat proses pemahaman. Salah satunya dengan cara memberi contoh kepada anggota melalui demonstrasi pengelolaan makanan. Upaya tersebut menyebabkan anggota dapat mencermati setiap proses yang berlangsung sehingga mereka dapat menanyakan secara langsung setiap permasalahan yang dihadapi. Melalui pemilihan metode yang tepat, tingkat pengetahuan anggota terhadap makanan menjadi meningkat. Selain itu, pengetahuan terhadap proses pengolahan, pengemasan hingga closing menjadi semakin mendalam. Saat ini para anggota tidak hanya sekedar mengetahui proses pengelolaan makanan namun mereka mampu menerapkan informasi yang diperoleh sehingga menghasilkan makanan yang sehat dan higienis. Sebelum mengikuti program pemberdayaan, para anggota hanya sekedar mengolah makanan namun belum memperhatikan kandungan gizi sehingga rasa makanan menjadi elemen utama. Keikut sertaan dalam program pemberdayaan menyebabkan para anggota memperoleh informasi mengenai kandungan gizi pada setiap bahan baku, baik ketika sebelum diolah hingga setelah mengalami proses pemasakan. Mereka menjadi lebih paham bahwa kandungan gizi pada tiap makanan akan berubah ketika mengalami proses pemasakan sehingga perlu memahami cara mengelola kandungan gizi untuk menghindari penyusutan.

\subsubsection{Sikap}

Perilaku anggota IbIKK Boga Ganesha yang ditinjau dari aspek sikap termasuk dalam kategori sangat baik dengan memperoleh skor 4,8. Data tersebut menunjukkan bahwa bahwa para anggota merespon secara positif terhadap pelaksanaan program pemberdayaan. Secara rinci aspek sikap dapat dicermati pada Tabel 3.

Tabel 3.

Sikap Anggota IbIKK Boga Ganesha, Tahun 2016

\begin{tabular}{|c|c|c|c|}
\hline No & Aspek & Pencapaian Skor & Kategori \\
\hline 1 & $\begin{array}{l}\text { IbIKK Boga Ganesha rutin menjaga } \\
\text { kebersihan dan kerapian dapurserta } \\
\text { ruang penerimaan tamu. }\end{array}$ & 4,92 & Sangat baik \\
\hline 2 & $\begin{array}{l}\text { Memberi senyuman dan bersikap ramah } \\
\text { dilaksanakan secara konsisten oleh } \\
\text { IbIKK Boga Ganesha ketika melayani } \\
\text { konsumen. }\end{array}$ & 4,92 & Sangat baik \\
\hline 3 & $\begin{array}{l}\text { Kebersihan dan kehigienisan semua } \\
\text { peralatan dan tempat kerja dilakukan } \\
\text { secara rutin oleh IbIKK Boga Ganesha } \\
\text { ketika aktivitas melayani konsumen } \\
\text { berakhir. }\end{array}$ & 4,70 & Sangat baik \\
\hline & Sikap & 4,8 & Sangat baik \\
\hline
\end{tabular}


Tabel 3 menunjukkan bahwa tiga parameter pada aspek sikap mencapai skor sangat baik. Para anggota menyadari bahwa makanan tradisional yang ditawarkan IbIKK Boga Ganesha lebih aman dikonsumsi dibandingkan fastfood. Selain itu, mereka memiliki keyakinan terhadap kehigienisan alat dan bahan yang digunakan oleh IbIKK Boga Ganesha dalam memproduksi makanan. Berkaitan dengan hal tersebut mereka yakin terhadap kehalalan produk karena proses yang dilakukan telah sesuai dengan prosedur. Para anggota juga menyatakan bahwa produk IbIKK Boga Ganesha disajikan secara unik dan menarik. Untuk menjaga kehigienisan masakan, IbIKK Boga Ganesha rutin menjaga kebersihan dan kerapian dapur serta ruang penerimaan tamu. Guna menarik konsumen, IbIKK Boga Ganesha secara konsisten memberikan senyuman dan bersikap ramah sehingga ada kesan baik yang ditimbulkan. Para anggota juga setuju bahwa promosi produk IbIKK Boga Ganesha dilakukan dengan cara yang tepat.

Berkaitan dengan hal tersebut, pola sikap yang ditunjukkan oleh anggota IbIKK Boga Ganesha dipengaruhi oleh beberapa faktor sehingga terjadi perubahan sikap. Salah satu faktor internal adalah pengalaman pribadi yang dialami oleh para anggota. Pengalaman pribadi harus meninggalkan kesan yang kuat sehingga dapat menjadi dasar pembentukan sikap.Para anggota yang pada awalnya kurang menerima budaya baru yang coba dibiasakan pada program pemberdayaan secara perlahan mengikuti hingga akhirnya menerima kebudayaan baru tersebut. Mereka merasakan manfaat positif yang ditimbulkan oleh budaya baru tersebut.

\subsubsection{Keterampilan}

Keunikan dan keunggulan IbIKK Boga Ganesha dibandingkan dengan produk kuliner yang ada di Singaraja dan bahkan di Bali adalah jaminan sehat dengan nutrisi yang lengkap dan seimbang. Makanan sehat yang dimaksud sangat dipengaruhi oleh kualitas bahan, proses pengolahannya, dan penyajian/pengemasannya. Kegiatan IbIKK Boga Ganesha didominasi oleh pengolahan dengan cara merebus atau mengukus untuk menjaga kesucian atau kehalalan produk. Cara-cara pengolahan yang bersih dan hiegienis serta penggunaan bahan-bahan organik juga dapat menjaga kesucian atau kehalalan produk makanan. Produk Boga Ganesha dihasilkan dari pemilihan bahan makanan yang berkualitas dan tersedia disekitar, tidak menggunakan penyedap rasa (bumbu harus cukup), pemakaian bahan tambahan alami seperti pewarna dari daun pandan, kunyit atau bit, resep tradisional yang dimodifikasi (mempertahankan ciri khas makanan tradisional), dan disajikan menggunakan peralatan saji tradisional seperti ingke (piring dari lidi).

Pemilihan IPTEKS produk makanan "Boga Ganesha" berdasarkan hasil penelitian dan temuan mahasiswa dan dosen di Program Studi Tata Boga Fakultas Teknik dan Kejuruan UNDIKSHA. Produk makanan tradisional sudah diuji cobakan untuk memperoleh produk makanan yang berkualitas, serta disesuaikan dengan selera konsumen. Pengujian tersebut dimaksudkan untuk meningkatkan nilai ekonomis bahan baku lokal sehingga secara psikologis memberi pengaruh positif. 


\subsection{Keberhasilan Pemberdayaan}

Hasil penelitian menunjukkan bahwa pemberdayan IbIKK Bogas Ganesha termasuk dalam kategori berhasil dengan skor 4,2. Data ini menunjukkan bahwa IbIKK Boga Ganesha berhasil dalam melaksanakan program yang direncanakan. Tabel 4 menunjukkan bahwa IbIKK Boga Ganesha berhasil melaksanakan program pemberdayaan kepada masyarakat. Keberhasilan pelaksanaan program pemberdayaan dapat dilihat dari berbagai hal. Keberhasilan suatu program pemberdayaan secara umum dapat dilihat dari aktifnya seluruh anggota dalam menghadiri pelatihan.Kegiatan yang diikuti secara berkesinambungan akan berpengaruh terhadap keterampilan yang dimiliki oleh anggota. Anggota IbIKK Boga Ganesha dapat mengaplikasikan materi dengan lengkap dan benar. Berhasilnya suatu pelaksanaan program pemberdayaan juga dapat dilihat dari keaktifan anggota dalam menyampaikan ide-ide baru yang dirasa lebih efektif dan efisien bila dilaksanakan.

Keberhasilan utama yang dituju dalam pelaksanaan program pemberdayaan adalah anggota IbIKK Boga Ganesha mengimplementasikan seluruh hal yang di dapat dari pelatihan untuk meningkatkan mutu hidup dan para anggota mampu menentukan keputusan akhir dan bertanggungjawab atas setiap keputusan yang dilaksanakan.Secara rinci aspek keberhasilan pemberdayaan dapat dicermati pada Tabel 4.

Tabel 4.

Keberhasilan Pemberdayaan IbIKK Boga Ganesha Tahun 2016

\begin{tabular}{|c|c|c|c|}
\hline No & Aspek & Pencapaian skor & Kategori \\
\hline 1 & $\begin{array}{l}\text { Anggota IbIKK Boga Ganesha mengikuti } \\
\text { seluruh rangkaian pelatihan yang diagendakan }\end{array}$ & 4 & Berhasil \\
\hline 2 & $\begin{array}{l}\text { Semua anggota IbIKK Boga Ganesha dapat } \\
\text { mengaplikasikan materi dengan lengkap dan } \\
\text { benar }\end{array}$ & 4,2 & Berhasil \\
\hline 3 & $\begin{array}{l}\text { Semua anggota IbIKK Boga Ganesha } \\
\text { berpartisipasi dalam pengumpulan dana } \\
\text { operasional kegiatan pelatihan }\end{array}$ & 4,2 & Berhasil \\
\hline 4 & $\begin{array}{l}\text { Pada setiap pelaksanaan kegiatan, panitia } \\
\text { memberikan lebih dari satu solusi pada setiap } \\
\text { permasalahan }\end{array}$ & 4,25 & Sangat berhasil \\
\hline 5 & $\begin{array}{l}\text { Semua anggota IbIKK Boga Ganesha } \\
\text { mengikuti seluruh rangkaian pelatihan }\end{array}$ & 4 & Berhasil \\
\hline 6 & $\begin{array}{l}\text { Semua anggota IbIKK Boga Ganesha } \\
\text { mengalami peningkatan pendapatan pasca } \\
\text { mengikuti pelatihan }\end{array}$ & 4,25 & Sangat berhasil \\
\hline 7 & $\begin{array}{l}\text { Anggota IbIKK Boga Ganesha } \\
\text { mengimplementasikan seluruh hal yang di } \\
\text { dapat dari pelatihan untuk meningkatkan mutu } \\
\text { hidup }\end{array}$ & 4,2 & Berhasil \\
\hline 8 & $\begin{array}{l}\text { Pasca mengikuti pelatihan, anggota IbIKK } \\
\text { Boga Ganesha mampu menentukan keputusan } \\
\text { akhir dan bertanggungjawab atas setiap } \\
\text { keputusan yang dilaksanakan }\end{array}$ & 4,33 & Sangat berhasil \\
\hline & Keberhasilan pemberdayaan & 4,2 & Berhasil \\
\hline
\end{tabular}


Kesimpulan dari uraian di atas, yaitu (a) pemberdayaan sangat menekankan pentingnya partisipasi masyarakat, baik pada tehap perencanaan, pelaksanaan, maupun pengembangannya, (b) pemberdayaan selalu tidak memisahkan antara pembengunan fisik proyek dengan pelatihan keterampilan dan (c) sumber dana bagi kegiatan pemberdayaan masyarakat umumnya berasal dari anggaran pemerintah, partisipasi pihak swasta, dan dari partisipasi masyarakat sendiri (Sumaryadi, 2005).

\section{Simpulan dan Saran}

\subsection{Simpulan}

Berdasarkan hasil penelitian, potensi yang dimiliki oleh IbIKK Boga Ganesha adalah olahan pangan tradisional yang halal, higienis, dan sehat. Perilaku yang ditunjukan para anggota termasuk kategori sangat baik dengan skor 4,6. Data tersebut menunjukkan bahwa para anggota sangat mendukung dan turut serta dalam pelaksanaan program yang direncanakan. Hal tersebut sesuai dengan pencapaian pelaksanaan program pemberdayaan yang termasuk dalam kategori berhasil dengan skor 4,2. Data ini menunjukkan bahwa IbIKK Boga Ganesha berhasil mendorong para anggota untuk mengimplementasikan ilmu yang diperoleh.

\subsection{Saran}

Fasilitator hendaknya menggunakan metode yang tepat sehingga seluruh peserta dapat menyerap informasi secara merata dengan demikian dapat meningkatkan kualitas sumber daya manusia, baik dari aspek pengetahuan, keterampilan dan sikapnya.

\section{Ucapan Terima Kasih}

Penulis menyampaikan terimakasih kepada kelompok IbIKK Boga Ganesha yang telah memberikan kemudahan dalam memperoleh berbagai informasi. Tidak lupa penulis ucapkan terimakasih kepada keluarga dan kerabat yang telah membantu dan memberikan dukungan baik secara moril maupun dalam peruses penyelesaian journal ini.

\section{Daftar Pustaka}

BPS Provinsi Bali. 2014.Jumlah dan Persentase Penduduk Miskin di Provinsi Bali Menurut Kabupaten/Kota Tahun $2011 \quad-\quad 2013 . \quad$ \{Internet\}. http://bali.bps.go.id/tabel_detail. Diunduh pada tanggal 14 Mei 2015.

Chamdi, A.N. 2003. Kajian Pofil Sosial Ekonomi Usaha Kambing di Kecamatan Kradana Kabupaten Grobogan. Jakarta: PT Pradnya Paramita.

Coleman, J.S. 1988. Social Capital in the Creation of Human. The American Journal of Sociology. 94 (Suppl): 95-120. American: The University of Chicago Press.

Noor, J. 2011. Metodologi Penelitian.: Skripsi, Tesis, Disertasi dan Karya Ilmiah. Jakarta : Kencana (Prenada Media Group).

Putnam, R.D. 2001. Bowling Alone:The Collapse and Revival of American Community. New York. Simon \& $\quad$ Schuster. 
http://xroads.virginia.edu/ HYPER/DETOC/assoc/bowling.html. Diunduh tanggal 7 Oktober 2015.

Resmining, I. 2014. Keunggulan dan Potensi Masakan Indonesia. Surakarta : Penerbit Aryhaeko Sinergi Persada.

Soekartawi, 1986. Ilmu Usaha Tani dan Penelitian Untuk Pengembangan Petani. Jakarta : UI Press.

Sumaryadi, I.N. 2005.Pembangunan Daerah Otonomi \& Pemberdayaan masyarakat. Jakarta : Citra Utama.

Wirawan, N. 2001. Cara Mudah Memahami Setatistik 1 (Statistik Diskriptif). Denpasar: Kerang Emas.

Worthington, B.S. 2000. Hubungan Antara Konsumsi Lemak dan Serat Dalam Setatus Gizi. Jakarta : Buku Kedokteran EGC. 